\title{
Tratamento cirúrgico da cifose patológica
}

\author{
Surgical treatment of pathological kyphosis
}

Helton luiz Aparecido Defino ${ }^{1}$, Andrés Edgard Rodriguez-Fuentes² e Flávio P. PIola ${ }^{3}$

\section{RESUMO}

Foram estudados 13 pacientes com cifose patológica de diferentes etiologias (Doença de Scheuermann, espondilite anquilosante, congênita, tuberculose vertebral, sequela de laminectomia e síndrome de Morquio), que foram submetidos ao tratamento cirúrgico.

A cifose pré-operatória variou de 75 a 100 graus (média 73,3 graus) e a média dos valores após o tratamento cirúrgico foi de 42,3 graus.

O tipo de tratamento realizado estava relacionado com as características da cifose (raio longo ou curto, flexibilidade e magnitude), e são apresentadas as diferentes técnicas e filosofia de tratamento dos autores para o tratamento cirúrgico dessa modalidade de deformidade vertebral.

Descritores: Deformidade vertebral; Cifose vertebral; Tratamento cirúrgico da cifose

\section{INTRODUÇÃO}

A coluna vertebral apresenta 4 curvaturas no plano sagital (lordose cervical, cifose torácica, lordose lombar e cifose sacro-coccígea), que são balanceadas e cuja presença tem sido interpretada sob o ponto de vista biomecânico, como possuindo o objetivo de aumentar a resistência mecânica da coluna vertebral, aumentar a sua capacidade de absorção de choques e também a sua flexibilidade ${ }^{(1,3)}$.

Existe muita controvérsia com relação aos limites da normalidade das curvas sagitais da coluna lombar. Na coluna torácica os valores acima de 50 a 55 graus são considerados como deformidade cifótica, e na coluna cervical ou lombar, qualquer curvatura de angulação dorsal pode ser considerada como cifose patológica. ${ }^{(2,4,9)}$

\section{SUMMARY}

Thirteen patients with pathologic kyphosis from different ethiologies (Scheuermann's disease, ankylosing spondilitis, congenital, vertebral tuberculosis, post laminectomy and Morquio's syndrome) who underwent surgical treatment were studied. Preoperative kyphosis ranged from $75^{\circ}$ to $100^{\circ}$ (average $73.3^{\circ}$ ) and postoperatively averaged $42.3^{\circ}$.

The treatment performed was based on kyphosis characteristics (long or short radius, flexibility, magnitude). The different techniques are presented as well as authors' philosophy for surgical treatment of this kind of vertebral deformity.

Key Words: Spinal deformity; Kyphosis; Surgical treatment

\section{INTRODUCTION}

The spine presents 4 balanced sagittal curves (cervical lordosis, thoracic kyphosis, lumbar lordosis and sacrumcoccigeal kyphosis), which presence has been interpreted from a biomechanical point of view as increasing mechanic resistance of the spine, increasing its ability to absorb shocks as well as its flexibility ${ }^{(1,3)}$.

Normal limits of vertebral sagittal curves is controversial. At thoracic spine, values above 50 to $55^{\circ}$ are considered as a kyphotic deformity and at cervical or lumbar spine, any curve with a dorsal angulation may be considered as a pathologic kyphosis $^{(2,4,9)}$.

Etiology of pathologic kyphosis includes a number of diseases (congenital, growth alterations, trauma, tumors, infectious processes, degenerative or iatrogenic) which disturb spine biomechanics in its basic functions. (Figure 1). Ele-
*Trabalho realizado no Departamento de Biomecânica, Reabilitação e Medicina do Aparelho Locomotor da Faculdade de Medicina de Ribeirão Preto-USP.

1- Professor Associado

2- Professor Doutor

3- Médico Adido

Endereço para correspondência: Faculdade de Medicina de Ribeirão Preto - USP Av. Bandeirantes, 3900 - Ribeirão Preto - SP - Brasil - Cep: 14049-900

Fone: (16) 602-3000 - E-mail - hladefin@fmrp.usp.br
*Work performed at the Biomechanics Departament, Medicine and Rehabilitation of Locomotor System fron Faculdade de Medicina de Ribeirão Preto-USP.

1- Associate Professor

2- PhD Professor

3- Assistant Doctor

Adress: Faculdade de Medicina de Ribeirão Preto - USP

Av. Bandeirantes, 3900 - Ribeirão Preto - SP - Brasil

Cep: 14049-900 - Fone: (16) 602-3000 - E-mail - hladefin@fmrp.usp.br 
A etiologia da cifose patológica abrange um grande número de doenças (congênitas, distúrbios do crescimento, trauma, tumores, processos infecciosos, degenerativas ou iatrogênicas) que alteram a biomecânica da coluna vertebral nas suas funções básicas. (Figura 1). Os elementos da parte anterior da coluna vertebral (corpo vertebral e disco intervertebral) resistem às forças de compressão, e os elementos posteriores (lâmina, articulações, ligamentos supra e interespinhoso) resistem às forças de tração. A deformidade cifótica ocorre quando a

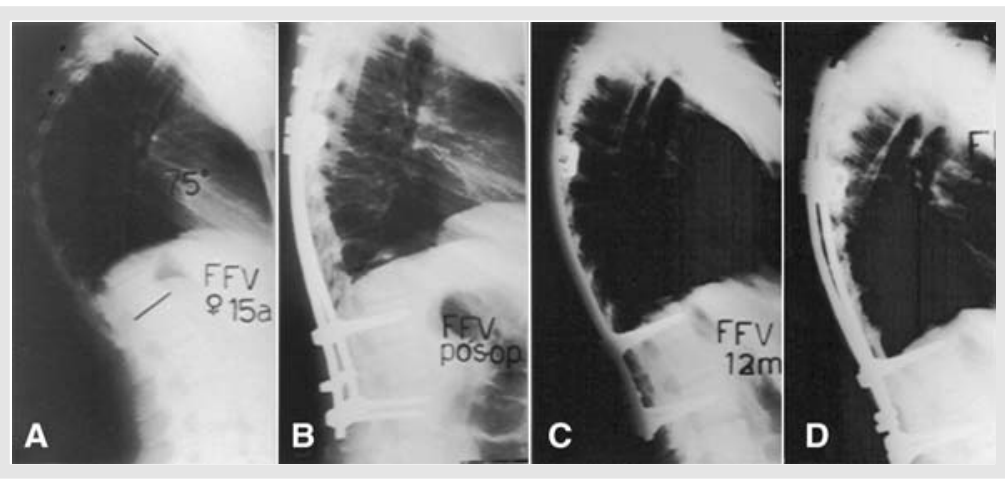

Figura1 - FFV-sexo masculino- 15anos de idade. Doença de Scheuermann. Radiografia pré-operatória em perfil (A). Radiografia pós-operatória em perfil após a realização da liberação e artrodese anterior associada com instrumentação e artrodese posterior (B), com 12 meses de pós-operatório (C) e 36 meses de pós-operatório (D).

Figure 1 - FFV-male- 15 years old. Scheuermann's Disease.

Preoperative radiograph (A). Postoperative radiograph after anterior release plus arthrodesis, as posterior instrumentation and arthrodesis (B), 12 months postoperative $(C)$ and 36 months postoperative $(D)$. ments taking part in anterior portion of the spine (vertebral body and intervertebral disc) resist to compression forces and the posterior ones (lamina, joints, supra and interespinous ligaments) resist traction forces. A kyphotic deformity takes place when the spine is unable to resist to one or both forces (compression or traction) $)^{(10,11)}$.

Treatment of pathologic kyphosis is to be surgical, except in the case of Scheuermann's Disease with angles below 70 to $75^{\circ}$, which present good results with coluna vertebral é incapaz de resistir a uma ou ambas as forças (compressão ou tração) ${ }^{(10,11)}$.

O tratamento da cifose patológica é cirúrgico, com exceção da Doença de Scheuermann com valores angulares abaixo de 70 a 75 graus, que apresenta bons resultados com o tratamento conservador ${ }^{(6)}$. O tipo de tratamento cirúrgico empregado no tratamento da cifose patológica está intimamente relacionado às características biomecânicas e morfopatológicas da deformidade, e também à presença de compressão das estruturas nervosas, existindo muitas opções técnicas para resolver esse problema ${ }^{(5,6)}$.

O objetivo desse trabalho é apresentar os resultados do tratamento cirúrgico da cifose patológica de diferentes etiologias, com base em parâmetros clínicos e radiológicos de avaliação, e ilustrar os métodos de tratamento cirúrgico que temos utilizado.

\section{MATERIAL E MÉTODOS}

Foram avaliados 13 pacientes que apresentavam cifose patológica de diferentes etiologias e que foram submetidos ao tratamento cirúrgico no Hospital das Clínicas da Faculdade de Medicina de Ribeirão Preto-USP.

As características gerais dos pacientes estão ilustradas na (Tabela 1). A cifose patológica era devido à Doença de Scheuermann em 5 pacientes, espondilite anquilosante em 3, congênita em 2, tuberculose vertebral em 1, seqüela de lâminectomia para remoção de tumor de origem neural em 1, e Síndrome de Mórquio em 1 paciente.A idade dos pacientes variou de 9 a 60 anos (média 24 anos), e 6 eram do sexo masculino e 7 do sexo feminino.A deformidade estavalocalizada na coluna torácica em 3 pacientes e na coluna tóraco-lombar em 10 pacientes.

O grau de cifose pré-operatória variou de 75 a 100 graus (média 73,3 graus) no grupo de pacientes estudados. Na coluna torácica a cifose variou de 75 a 100 graus e na coluna tóraco- conservative treatment ${ }^{(6)}$. The surgical treatment chosen for each pathologic kyphosis is closely related to biomechanic characteristics of the deformity, and also to the presence of nervous structures compression, with many different technical options to solve it ${ }^{(5,6)}$.

The objective of this work is to report the results of surgical treatment of pathologic kyphosis from different etiologies based on evaluation parameters of clinical and radiographic nature, and to illustrate the surgical treatment methods we have been using.

\section{MATERIAL AND METHODS}

Thirteen patients who presented with pathologic kyphosis from different etiologies and underwent surgical treatment at Hospital das Clínicas da Faculdade de Medicina de Ribeirão Preto - USP were evaluated.

General characteristics of the patients are in Table 1. Pathologic kyphosis was due to Sheuermann's Disease in 5 patients, ankylosing spondilitis in 3, congenital in 2, vertebral tuberculosis in 1, post laminectomy (for resection of a neural tumor) in 1 and Morquio syndrome in 1 patient. Age ranged from 9 and 60 years (average 24 years); 6 were male, 7 female. The deformity was at thoracic spine in 3 patients, and thoracic and lumbar in 10 patients.

The degree of pre operative kyphosis ranged from 75 to $100^{\circ}$ (average $73.3^{\circ}$ ) in this group of patients. In thoracic spine the kyphosis ranged from 75 to $100^{\circ}$ and in thoracic and lumbar spine from 45 to $88^{\circ}$. The deformity was rigid in 4 patients and flexible in the remaining 9. Two patients had neurologic deficit (lower limbs paresis with piramidal release signs) (Figure 4)

The treatment was related to kyphosis characteristics (long 


\begin{tabular}{|c|c|c|c|c|c|c|c|c|c|c|c|}
\hline Paciente & Sexo 1 & Idade & Etiologia & Localização & Neurológico & $\begin{array}{c}\text { Cifose } \\
\text { pré-operatória }\end{array}$ & Tratamento & Fixação & $\begin{array}{c}\text { Cifose } \\
\text { pós-operatória }\end{array}$ & Encherto & Complicações \\
\hline 1 & M & 60 & Espond.anquilos & Tóraco-lombar & normal & 55 & Osteotomiaposterior & USIS & 50 lordose & illíaco & Solt.impl ereop \\
\hline 2 & $\mathrm{~F}$ & 35 & Espond.anquilos & Tóraco-lombar & normal & 45 & Osteotomiaposterior & USIS & 30 lordose & ilíaco & Nenhuma \\
\hline 3 & $\mathrm{~F}$ & 20 & D.Scheuermann & Tóraco-lombar & normal & 62 & Artrodese e fixação posterior & Contrel-Dubousset & 30 & ilíaco & Nenhuma \\
\hline 4 & $\mathrm{~F}$ & 22 & D.Scheuermann & Tóraco-lombar & normal & 60 & Artrodese e fixação posterior & Contrel-Dubousset & 30 & ilíaco & Nenhuma \\
\hline 5 & $\mathrm{~F}$ & 17 & D.Scheuermann & Tóraco-lombar & normal & 75 & Artrodese e fixação posterior & Contrel-Dubousset & 35 & llíaco & Infecção superficial \\
\hline 6 & M & 9 & S. deMóquio & Tóraco-lombar & normal & 45 & Artrodese anterior & Nenhuma & 45 & Fibula & Nenhuma \\
\hline 7 & M & 16 & Congênita & Torácica & alterado & 100 & Desc.ant. eartrod.posterior & Nenhuma & 100 & Fibula & Nenhuma \\
\hline 8 & $\mathrm{~F}$ & 32 & Tuberculose & Torácica & normal & 75 & Artrodese anterior e posterior & USIS & 50 & Fibula & Nenhuma \\
\hline 9 & M & 32 & Espond.anquilos & Tóraco-lombar & normal & 80 & Osteotomiaposterior & USIS & 35 lordose & illíaco & Nenhuma \\
\hline 10 & M & 16 & D.Scheuermann & Tóraco-lombar & normal & 88 & Artrodese posterior & Contrel-Dubousset & 30 & ilíaco & Nenhuma \\
\hline 11 & M & 18 & D.Scheuermann & Torácica & normal & 90 & Osteotomia posterior & USIS & 50 & ilíaco & Quebra parafuso \\
\hline 12 & $\mathrm{~F}$ & 17 & Congênita & Tóraco-lombar & alterado & 85 & Desc.ante artrod.posterior & USIS & 30 & ilíaco & Nenhuma \\
\hline 13 & $\mathrm{~F}$ & 18 & Sequela ressec.tumor & Tóraco-lombar & normal & 78 & Liber.ante artrod.posterior & Contrel-Dubousset & 30 & ilíaco & Nenhuma \\
\hline
\end{tabular}

Tabela I - Características gerais dos pacientes.

Table I - General patients' characteristics.

lombar de 45 a 88 graus. A deformidade era rígida em 4 pacientes e flexível nos outros 9. Dois pacientes apresentavam déficit neurológico (paresia de membros inferiores acompanhada de sinais de liberação piramidal)(Figura 4).

O tipo de tratamento realizado estava relacionado com as características da cifose (raio longo ou curto, flexibilidade e magnitude). Nas curvas de raio longo e flexíveis era inicialmente realizada a instrumentação e artrodese posterior, seguida de artrodese anterior, enquanto que nas curvas de raio longo e rígidas, inicialmente era realizada a liberação e artrodese anterior, seguida da instrumentação e artrodese posterior(Figura 1). Nos pacientes portadores de espondilitite anquilosante foi realizada a osteotomia posterior uni ou multisegmentar, seguida de fixação e artrodes posterior (Figura 2). A osteotomia posterior acompanhada de fixação e artrodese, segundo a técnica ${ }^{(7)}$, foi realizada em 1 paciente com doença de Scheuermann. (Figura 3)

Nas curvas de raio curto com cifose angular e rígida, inicialmente era realizada a liberação anterior e descompressão das estruturas nervosas quando necessário, seguida da artrodese anterior e posterior, tendo sido realizada a fixação posterior quando as condições do tecido ósseo permitia.

Nas curvas rígidas e nas quais havia a inten-

or short radius, flexibility, magnitude). In long radius and flexible curves, a posterior instrumentation and arthrodesis was initially performed, followed by anterior arthrodesis, while in long radius rigid curves it was initially performed an anterior release followed by a posterior instrumentation and arthrodesis (Figure 1). In patients with ankylosing spondilitis a posterior osteotomy, uni or multisegmental was performed, followed by a fixation and posterior arthrodesis (Figure 2). Posterior arthrodesis followed by fixation and arthrodesis, according to the technique ${ }^{(7)}$ was performed in one patient with Sheuermann's disease (Figure 3).

In short radius curves, with an angular and rigid kyphosis, it was initially performed an anterior release and decompression of nerve structures

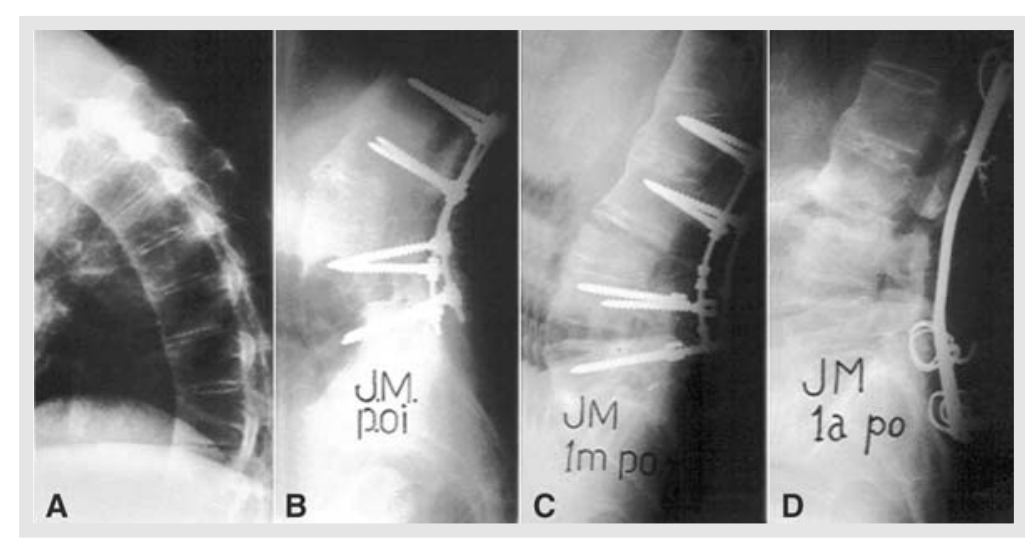

Figura 2 - JM - sexo masculino- 60 anos de idade. Espondilite anquilosante. Radiografia pré-operatória em perfil (A). Radiografia pós-operatória em perfil, após a realização de osteotomia monosegmentar e fixação transpedicular (B). Perda da correção e soltura dos implantes após queda (C). Radiografia 1 ano após a reoperação (D).

Figure 2 - JM - male - 60 years old. Ankylosing spondilitis.

Preoperative radiograph $(A)$. Postoperative radiograph after a monosegmental osteotomy and trans-pedicullar fixation (B). Correction lost and implants loosening after a fall (C). Radiograph 1 year after reoperation (D). as necessary, followed by anterior and posterior arthrodesis, and posterior fixation whenever allowed by bone tissue status.

In rigid curves where it was not intended an angular correction, the treatment was in three steps, starting with a posterior release, followed by an anterior release and arthrodesis, with a posterior fixation with arthrodesis (Figures 4 and 5).

Posterior instrumentation was used in 11 patients, using a pedicular screws system (USIS) in 6 patients; hooks and pedicular screws (Co- 
ção da correção angular, o tratamento era realizado em 3 etapas, tendo sido iniciado pela liberação posterior, seguido da liberação e artrodese anterior, e fixação e artrodese posterior. (Figuras 4 e 5)

A instrumentação posterior foi utilizada em 11 pacientes, tendo sido utilizado sistema de parafusos pediculares (sistema USIS) em 6 pacientes; sistema de ganchos e parafusos pediculares (Cotrel-Dubousset) em 5 pacientes. Em 2 pacientes não foi utilizado sistema de fixação, tendo sido realizada somente a artrodese anterior em 1 paciente e descompressão e artrodese anterior associada com artrodese posterior no outro paciente.

A artrodese anterior foi realizada em 6 pacientes, tendo sido utilizado enxerto córtico-esponjoso em 4 pacientes e da fíbula em 3.

No período pós-operatório 4 pacientes não utilizaram imobilização, 8 utilizaram colete gessado e 1 paciente colete de Jewett, por um período que variou de 3 a 9 meses (média 4,7 meses).

Os principais parâmetros avaliados nesse grupo de pacientes estudados foram à correção radiográfica da deformidade e a sua manutenção durante o seguimento dos pacientes, a integração do enxerto ósseo, a melhora do quadro neurológico e a melhora do aspecto estético.

\section{RESULTADOS}

Os pacientes foram seguidos por um período que variou de 12 a 36 meses (média 23,5 meses).

A correção radiográfica da deformidade ocorreu em 11 dos 13 pacientes, e a cifose média no pré-operatório que era de 73,3 graus, passou para 42,3 graus no pós-operatório. A correção da cifose não foi observada em um paciente portador de Síndrome de Morquio em que foi realizada somente a artrodese anterior e em

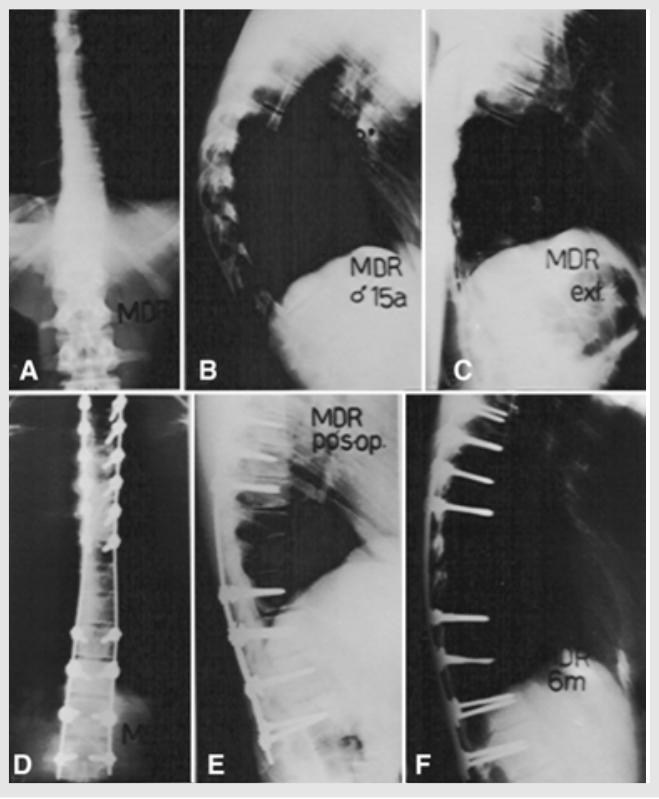

Figura 3 - MRD - sexo masculino- 15 anos de idade Doença de Scheuermann. Radiografias préoperatórias em $A P(A)$, perfil $(B)$ e perfil em hiperextensão (C). Radiografias pós-operatórias ( $D, E$ e F) após a realização de osteotomias posteriores múltiplas (Técnica de Ponte \& Siccardi) e fixação transpedicular e artrodese posterior.

Figure 3 - MRD - male - 15 years old . Scheuermann's Disease. Preoperative $A P$ radiograph $(A)$, lateral $(B)$ and lateral in extension (C). Postoperative radiographs $(D, E$ and $F$ ) after performing multiple posterior osteotomies (Ponte \& Siccardi Technique) with transpedicullar fixation and

trel-Dubousset) in 5 patients. In two patients it was used no fixation, and in 1 patient only anterior arthrodesis was performed and anterior arthrodesis with decompression together with a posterior arthrodesis in another patient.

Anterior arthrodesis was performed in 6 patients, using cortico-cancellous grafting in 4 patients, and fibula in 3 .

In postoperative period, 4 patients didn't use any external immobilization, 8 used a plaster cast, 1 used a Jewett vest for a period ranging from 3 to 9 months (average 4.7 months).

The principal parameters evaluated in this group of patients was radiographic correction of the deformity and maintenance of the results $d u$ ring follow-up, bone graft integration, improvement of neurologic evaluation and esthetic result.

\section{RESULTS}

Patients were followed-up for a period ranging from 12 to 36 months (average 23.5 months).

Radiographic correction of the deformity was achieved in 11 of the 13 patients,

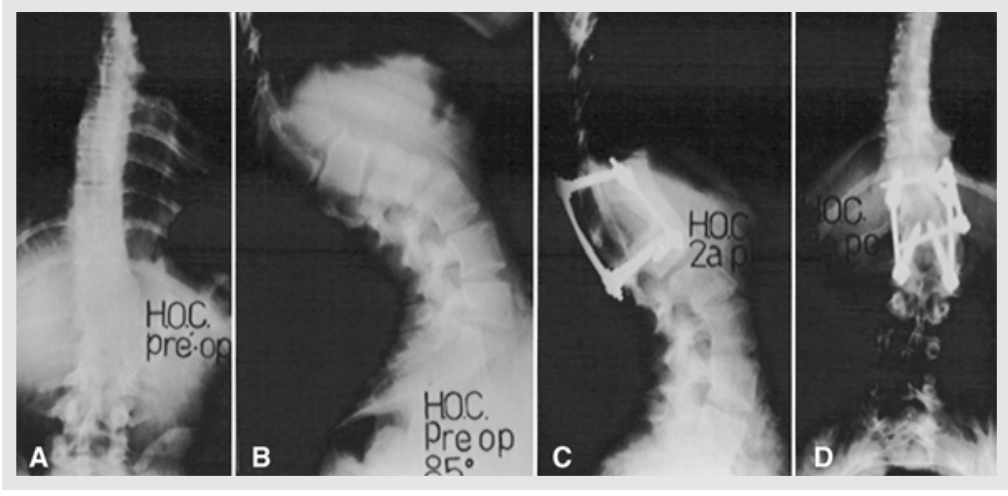

Figura 4 - HOC - sexo feminino - 17 anos de idade. Cifose congênita com compressão medular. A e $B-R x$ pré-operatório em $A P$ e perfil. Observar a hemivértebra no ápice da deformidade. C e $D$ - Aspecto radiográfico com 2 anos de pós-operatório, após a realização da liberação posterior, descompressão anterior e artrodese posterior. Houve remissão total do déficit neurológico. Figure 4 - HOC - female - 17 years old. Congenital kyphosis with medullar compression. A e $B$ - Preoperative radiographs. Notice hemivertebra at the deformity apex. C e D-Radiograph 2 years postoperative, after a posterior release, anterior decompression and posterior arthrodesis. Neurologic deficit remitted. and the kyphosis, which averaged $73.3^{\circ}$ degree pre operatively changed to $42.3^{\circ}$ post operative. Correction was not observed in one patient with Morquio's syndrome, in who only an anterior arthrodesis was performed, and in another patient who presented with medullar compression and was submitted to anterior decompression, together with a posterior arthrodesis without instrumentation due to the status of the bone tissue.

The remaining patients displayed an important deformity correction, 
outro paciente que apresentava compressão medular e foi realizada a descompressão anterior, associada a artrodese posterior sem instrumentação, devido às condições do tecido ósseo. Nos demais pacientes foi observado importante correção da deformidade, que estava diretamente relacionada à flexibilidade da deformidade, liberação dos tecidos envolvidos na deformidade e instrumentação do segmento vertebral envolvido (Figuras 6 e 7).A manutenção da correção da deformidade tem sido observada nos pacientes, e perda de cerca de 5 graus foi observada em 4 pacientes, sem apresentar qualquer repercussão no resultado do tratamento.
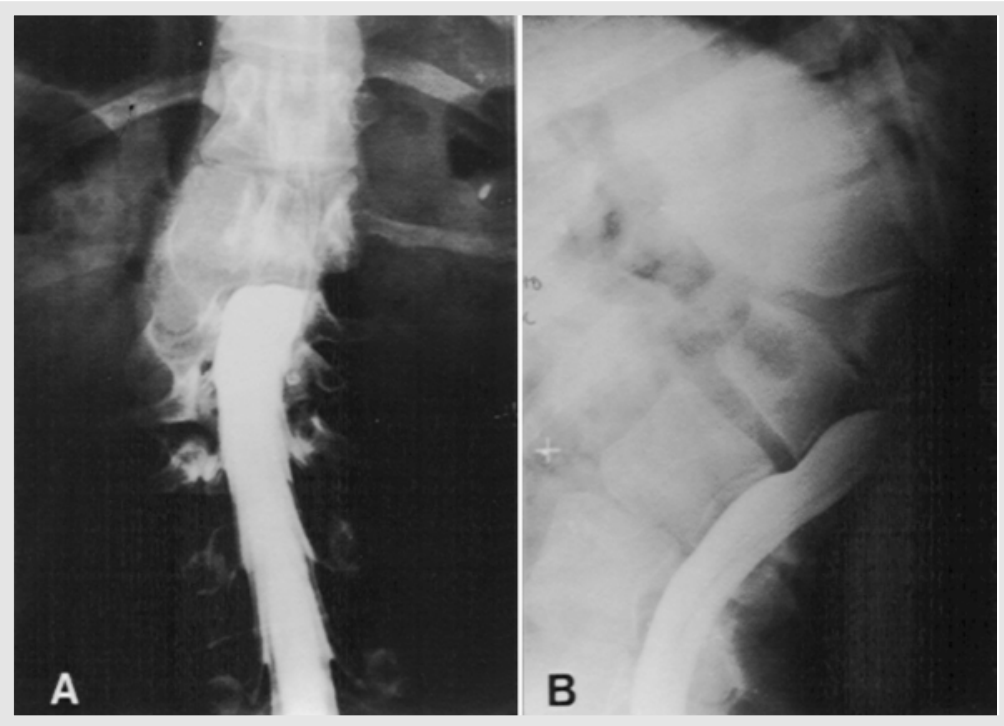

Figura 5 - HOC - sexo feminino- 17 anos de idade. Cifose congênita com sinais clínicos de compressão medular. Mielografia em AP (A) e perfil (B). Observar a compressão do canal vertebral ao nível da hemivértebra.

Figure $\mathbf{5}$ - HOC - female - 17 years old. Congenital kyphosis plus clinical signs of medullar compression. Mielography $A P(A)$ and lateral $(B)$. Notice vertebral canal compression at hemivertebra level. directly related to flexibility of the deformity, release of the involved tissues and instrumentation of the involved vertebral segment (Figures 6 and 7). Maintenance of the correction was observed, and a loss of $5^{\circ}$ was observed in 4 patients, with no repercussion on the treatment results.

Neurologic deficit remitted after decompression of vertebral canal in both patients presenting with lower limb paresis with signs of pyramidal release.

Complications observed were a superficial infection in 1 patient, deep infection in 1 patient, rupture of pedicular screw in 1 patient, loo-

Foi observado remissão do déficit neurológico após a descompressão do canal vertebral nos 2 pacientes que apresentavam paresia dos membros inferiores acompanhada de sinais de liberação piramidal.

As complicações observadas foram infecção superficial em 1 paciente, infecção profunda em 1 paciente, quebra de parafuso pedicular em 1 paciente, soltura dos implantes e perda da correção em 1 paciente (Figura 2) e dor no local da retirada do enxerto ósseo do ilíaco em 2 pacientes.

Após a realização do tratamento cirúrgico os pacientes eram capazes de exercer suas atividades profissionais de modo pleno, e a limitação funcional que foi observada em alguns, estava relacionada à doença de base como a espondilite anquilosante ou síndrome de Mor-
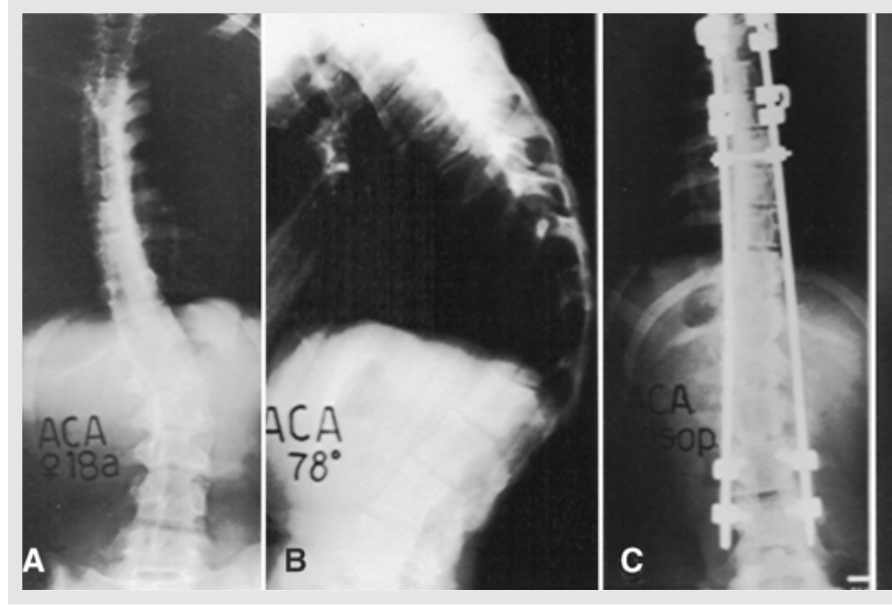

Figura 6 - ACA- sexo feminino- 18 anos de idade. Cifose após laminectomia para ressecção de Schawanoma. Radiografia pré-operatória em $A P(A)$ e perfil $(B)$. Radiografia pós-operatória em $A P(C)$ e perfil $(D)$ após a liberação e artrodese anterior, associada com instrumetação e artrodese posterior, realizadas no mesmo ato cirúrgico.

Figure 6 - ACA- female - 18 years old. Kyphosis after laminectomy for resection of a Schawanoma. Postoperative radiograph $A P(A)$ and lateral $(B)$. Postoperative radiograph in $A P(C)$ and lateral $(D)$ after anterior release plus arthrodesis, and posterior instrumentation and arthrodesis, performed at the same surgical procedure.

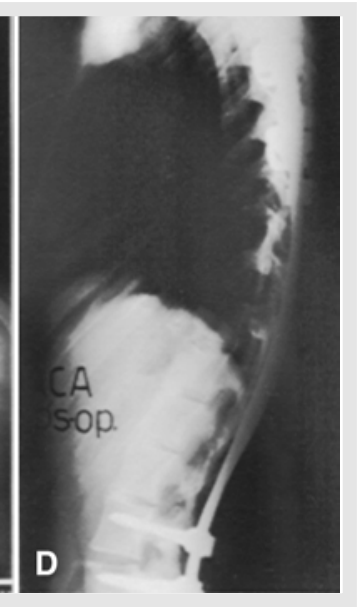

sening of the implants and loss of correction in 1 patient (Figure 2) and pain at the place bone graft was removed (iliac one) in 2 patients.

After surgical treatment patients were able to fully perform their professional activities, and the impairment found in some was related to the original disease, such as ankylosing spondilitis or Morquio's syndrome. In the remaining patients, after the surgery they could perform their usual professional activities, and were satisfied regarding correction of the deformity.

\section{DISCUSSION}

This study is composed by an heterogeneous group of kyphosis patients, and our main objecti- 
quio. Nos demais, após o tratamento cirúrgico os pacientes realizavam suas atividades profissionais, e existia uma satisfação com relação à correção da deformidade.

\section{DISCUSSÃO}

Esse estudo é composto por um grupo heterogêneo de pacientes portadores de cifose, e foi nosso objetivo principal apresentar alguns aspectos dessa modalidade de deformidade da coluna vertebral, associada à nossa filosofia atual de tratamento, que está diretamente relacionada às variáveis presentes nessa deformidade, como a flexibilidade, raio da curva e presença de déficit neurológico.

A cifose patológica é a expressão clínica e radiográfica de um grupo heterogêneo de doenças que atingem a coluna vertebral, e devido à falha da capacidade de suporte da porção anterior da coluna vertebral ou perda da resistência dos elementos posteriores aos esforços de tração, que podem ocorrer isoladamente ou em conjunto, resultam em deformidade progressiva da coluna vertebral, acompanhada algumas vezes de déficit neurológico pela compressão dos tecidos nervosos no interior do canal vertebral. À medida que a cifose progride, o eixo de suporte do peso do corpo desloca-se anteriormente, aumentando a tendência de progressão da cifose, e formando um círculo vicioso, que pode ser somente interrompido com a restauração do equilíbrio sagital da coluna vertebral. ${ }^{(1,8)}$

A compreensão do conceito do equilíbrio sagital da coluna vertebral e dos aspectos biomecânicos presentes nesse tipo de deformidade são fundamentais na elaboração do seu tratamento, que deve ainda considerar a "personalidade" da cifose, analisando a sua magnitude, raio, flexibilidade e presença de compressão das estruturas nervosas adjacentes. ${ }^{(5,6,10)}$

O maior grupo de pacientes nessa série, e também de nossa experiência com o tratamento cirúrgico, é representado pela cifose presente na doença de Scheuermann, cujo conceito de tratamento cirúrgico clássico recomenda a liberação das estruturas anteriores e colocação de enxerto entre os corpos vertebrais, associado a artrodese e instrumentação posterior, que permite a correção da deformidade em níveis altamente satisfatórios, como relatado pela literatura e observado emnossos pacientes. ${ }^{(5,6)}$ Nessa modalidade de cifose o tratamento inovador relatado nos últimos anos é o des-

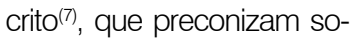
mente a abordagem posterior da deformidade, obten- ve in presenting such an study to present some aspects of this kind of spinal deformity, as well as our treatment philosophy, which is directly related to the different variables linked to the deformity, such as flexibility, curve radius and presence of a neurologic deficit.

Pathologic kyphosis is the clinical and radiographic expression of an heterogeneous group of diseases affecting the spine due to a supportive failure of the anterior part of the spine, or loss of resistance of the posterior elements to traction stress, which can be present both as isolated as together, resulting in a progressive deformity of the spine, sometimes joined by neurologic deficit due to compression of nervous tissues inside the vertebral canal. As the kyphosis progresses, the weight bearing axis displaces towards the front, increasing the trend of progressive kyphosis, so making a vicious circle only interrupted by restoring of the balance ${ }^{(1,8)}$.

Understanding the concept of sagittal balance of spine, as well as the biomechanical aspects which are present in this kind of deformity are fundamental in planning its treatment which should also take into consideration special features of the curve, such as radius, flexibility and nerve tissue compression $(5,6,10)$.

The largest group in this series, and also our experience in surgical treatment, is represented by Scheuermann's disease kyphosis, where the classical treatment recommends release of anterior structures and placement of bone graft between the vertebral bodies, associated to posterior arthrodesis plus instrumentation, allowing correction of the deformity in very satisfactory degrees as reported in the literature as well in as observed in our patients ${ }^{(5,6)}$.

In this kind of kyphosis, an innovative treatment recently proposed $^{(7)}$ recommen-

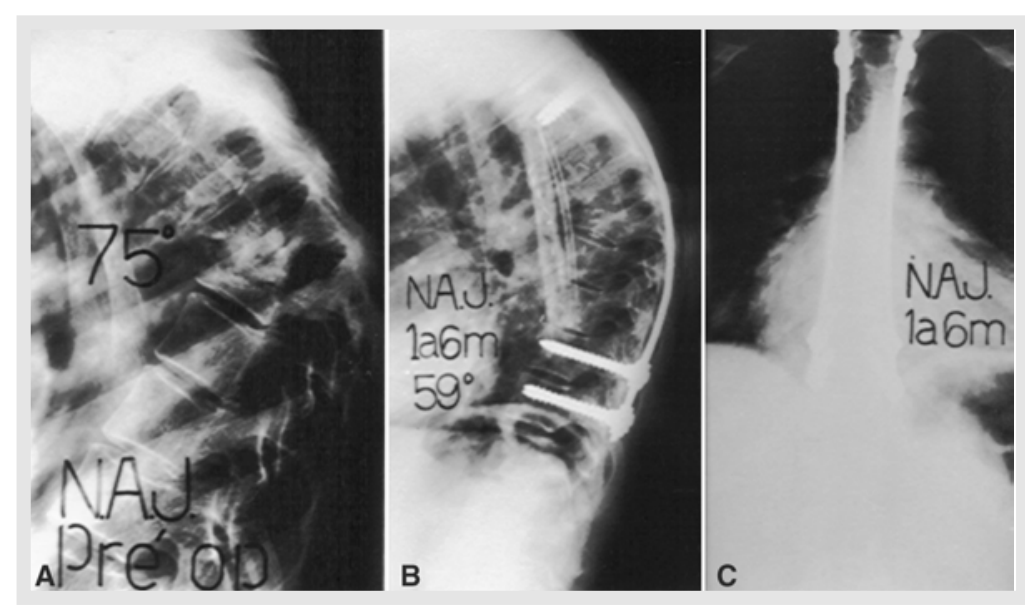

Figura 7 - NAJ- sexo feminino- 32 anos de idade. Tuberculose vertebral. Radiografia pré-operatória em perfil (A). Radiografia pós-operatória em perfil $(B)$ e $A P(C)$ com 1 ano e 6 meses de pós-operatório, após a fixação e artrodese posterior, associada com artrodese anterior utilizando enxerto de fíbula.

Figure 7 - NAJ- female - 32 years old. Spinal tuberculosis.

Preoperative radiograph (A). Postoperative radiograph lateral $(B)$ and $A P$ (C) 1 year and 6 months post operative, after posterior fixation and arthrodesis associated to anterior arthrodesis using fibular bone graft. ds only a posterior approach, with deformity correction through a posterior osteotomy at several levels, plus a posterior arthrodesis and instrumentation. This technique is less diffused among us, and, nevertheless our limited experience, it looks very much promising, and we believe that its greatest advantage is the performance of a single procedure, without need of a torachotomy, even though this procedure may currently be made esdoscopically.

In patients with ankylosing spondilitis we noticed in current literature a trend to perform subtraction osteotomy at 
do a correção da deformidade por meio da osteotomia posterior em vários níveis da coluna vertebral, associado à instrumentação e artrodese posterior. Essa técnica não é muito difundida em nosso meio, eapesar de nossa limitada experiência com a mesma, ela nos parece promissora, e acreditamos que sua grande vantagem consiste na realização de um procedimento único, sem a necessidade da abertura do tórax, ainda que esse procedimento possa ser realizado por via endoscópica no momento.

Nos pacientes portadores de espondilite anquilosante percebemos na literatura atual a tendência da realização de osteotomia de subtração em um único nível vertebra|(5,6), porém a realização de osteotomias múltiplas tem alcançado resultados muito satisfatórios em nossos pacientes, e temos preferido esse tipo de osteotomia nas situações em que os discos intervertebrais não estão anquilosados, reservando a indicação da osteotomia de subtração com ressecção do pedículo vertebral para as situações nas quais os discos intervertebrais estão anquilosados.

O desenvolvimento de novos sistemas de fixação vertebral tem possibilitado a melhor correção e manuseio da deformidade cifótica, desde que a natureza do tecido ósseo e outras variáveis relacionadas à rigidez da deformidade permitam a sua aplicação. Em algumas situações é possível a obtenção de correção da deformidade por meio da liberação posterior prévia, o que resulta na realização de 3 tempos cirúrgicos, como ilustrado no paciente da (Figura 4) . A adoção dessa conduta depende da filosofia de tratamento do cirurgião e do objetivo a ser alcançado no tratamento. Acreditamos que seja válida a realização de um tratamento mais complexo para a obtenção de melhores resultados estéticos, mas devemos reconhecer as situações nas quais a correção da deformidade pode aumentar a morbidade e o risco do tratamento, na qual o tratamento realizado deve ser realizado com o objetivo principal de recuperação do déficit neurológico e bloqueio da progressão da deformidade.

Com a disponibilidade dos novos sistemas de fixação, técnicas cirúrgicas, anestésicas e utilização do potencial evocado durante a cirurgia, os limites da correção e objetivos do tratamento estarão muito relacionados com a filosofia de tratamento e domínio das técnicas de correção, e somente os resultados a longo prazo com o emprego dessas técnicas permitiram a confirmação das melhores opções de tratamento dessa modalidade de deformidade vertebral.

\section{REFERÊNCIAS BIBLIOGRÁFICAS}

1. Bernhardt, M. \& Bridwell, KH. : Segmental analysis of the sagittal plane alignment of the normal thoracic and lumbar spines and thoracolumbar junction. Spine 14:717-721, 1989.

2. Carr, A.J., Jefferson, R.J.\& Turner-Smith, A.R., Beavis, A.: An analysis of normal back shape measurement by ISIS scanning. Spine, 16:656, 1991.

3. During, J., Goudfrooij, H., Keessen, W., Beeker, T.W. \& Crowe, A. : Postural characteristics of the lower back system in normal and pathologic conditions. Spine, 10: 83-87.

4. Fon, G.T., Pitt, M.. \& Theis, A.C. Jr. : Thoracic kyphosis: range in normal subjects. ARJ, 134: 979, 1980.

5. Hammerberg, K.W.: Kyphosis; in Bridwell, K.H. \& DeWald, R.L. (ed.) . The textbook of spinal surgery, Philadelphia, J.B. Lippincott Company, 1991,p. 501-523.

6. Holt, R.T., Dopf, C.A., Isaza, J.E., Rahn, K.A., Crawford, M.K. \& Kostuik, J.P.: Adult kyphosis; in Frymoyer, J.W. (ed.) The adult spine. one single level(5, 6), however multiple osteotomies have been reaching excellent results in our patients, and we've been preferring this procedure where intervertebral discs are not ankylosed, keeping the indication of subtraction osteotomy with vertebral pediculum resection for those situations where intervertebral discs are ankylosed.

Development of new vertebral fixation devices has allowed a better correction and handling of the kyphotic deformity, once bone tissue nature and other variables related to deformity rigidity make its use possible. In some situations it is possible to reach a correction of the deformity through a previous posterior release, resulting in 3 surgical times, as illustrated in patient in (Figure 4). This procedure depends on the treatment philosophy of the surgeon, and the treatment target. We believe that it is valid to use a more complex treatment to reach better esthetic results, however we should recognize that there are situations where deformity correction may result in increased morbidity and treatment risk, when the treatment is performed aiming mostly recovery of neurologic deficit and interruption of progression of the deformity.

As new fixation systems, surgical and anesthesic techniques, use of evoked potential during the procedure, become available, limits of correction and treatment targets will be closely related to treatment philosophy and skills in correction techniques, and only long term results using these techniques would allow confirmation of the best treatment options in this spinal deformity.

Principles and practices, $2^{\text {nd }}$ edition,. Philadelphia, Lippincott- Raven, 1997, p.1537- 1543.

7. Ponte, A. \& Siccardi, G.L. : The biomechanical advantage of an innovative posterior technique for correction of Scheuermann's kyphosis. Anals of the "First Combined Meeting of the Leading European Spine Societies.EuroSpine. October 16-19, 1996. ZürichSwitzerland.p.91.

8. Stagnara, P., Mauroy, J.C., Dran, G., Gonon, G.P., Constanzo,G., Dimnet, J. \& Pasquet, A. : Reciprocal angulation of vertebral bodies in a sagittal plane: approach to references for the evaluation of kyphosis and lordosis. Spine, 7:335-342, 1982.

9. Voutsinas, S.A. \& MacEwen, G.D. : Sagital profiles of the spine. Clin. Orthop., 210: 235, 1986.

10. White, A.A., Panajabi, M.M. \& Thomas, C.L. : The clinical biomechanics of kyphotic deformities. Clin. Orhtop., 128: 8-17, 1977.

11. Winter, R.B. \& Hall, J.E. : Kyphosis in childhood and adolescence. Spine, 3: 285-308, 1978. 